\title{
Effect of Organic Matter Amendment on Lead Contamination in Roadside Soil and Plant
}

\author{
Sabaruddin $^{1}$, Dedik Budianta ${ }^{1}$, and Mardia ${ }^{2}$ \\ Received 26 November 2009 / accepted 4 January 2010
}

\begin{abstract}
Lead Contamination in Roadside Soil and Plant and Effect of Organic Matter Amendment (Sabaruddin, D Budianta and Mardia): Roadside soils and plants may be the most important sink of lead ( $\mathrm{Pb})$. It has been widely known that soil organic matter (SOM) plays important roles in determining concentrations of metals in soil solution and their extractability from the soil. To investigate $\mathrm{Pb}$ contamination in the roadside soils and plants, as well as the effect of organic matter $(\mathrm{OM})$ on the soluble $\mathrm{Pb}$ in the roadside soils, surface soils (0 to $20 \mathrm{~cm})$ were collected from a busy road. The soils were incubated for 4 weeks under room temperature after being treated with $0,30,60$ and 90 $\mathrm{Mg} \mathrm{ha}^{-1}$ of OM. Leaves of oil palms (Elaeis guineensis) planted on the roadside were also analyzed for Pb content. Current study revealed that $\mathrm{Pb}$ content in roadside soils and leaves of oil palm was 1.5 and 5.5 times higher than the safe level of $\mathrm{Pb}$ in soil and plant. It confirms that both soil and plant at the study site were contaminated by $\mathrm{Pb}$. Current study also showed that $\mathrm{SOM}$ amendment significantly $(\mathrm{P}<0.01)$ affected soluble $\mathrm{Pb}$ content in the soils. Adding OM to the soil at $30 \mathrm{Mg} \mathrm{ha}^{-1}$ to correct the level of SOC from very low to low was sufficient to significantly reduce soluble $\mathrm{Pb}$ in the soils. However, the application of $60 \mathrm{Mg} \mathrm{ha}^{-1}$ of $\mathrm{OM}$ triggered the increases in soluble $\mathrm{Pb}$ in the soils. Further increases in $\mathrm{OM}$ application to $90 \mathrm{Mg} \mathrm{ha}^{-1}$ resulted in significant increases in soluble $\mathrm{Pb}$ as compared with that in the soil receiving $30 \mathrm{Mg} \mathrm{ha}^{-1}$ of OM. In spite of the increases, the level of soluble $\mathrm{Pb}$ in the soils receiving 60 and $90 \mathrm{Mg} \mathrm{ha}^{-1}$ of $\mathrm{OM}$ was still much below the safe level of $\mathrm{Pb}$ in soil.
\end{abstract}

Keywords: Organic matter, $\mathrm{Pb}$, roadside soil

\section{INTRODUCTION}

Heavy metal contamination in the environment is of major concern because the majority of the heavy metals are toxic to the living organisms and the environment, even those considered as essential can be toxic if present in excess (Chirenje et al. 2003; Dolan et al. 2006; Jarup 2003; Ma and Rao 1997; Silva et al. 2005). Heavy metals may come from many different sources, including vehicle emissions, industrial discharge and other activities (Gibson and Farmer 1986; Harrison et al. 1981; Li et al. 2001; Thornton 1991; Wu et al. 2006). However, the extensive use of automobile is one of the most important sources of heavy metal contamination in the roadside environment (Garcia and Millán 1994). Worldwide, leaded petrol has been reported to have caused more exposure to lead pollution in human beings than any other single source. Therefore, the USA, all European countries, and many developing countries have outlawed or strictly regulated the use of leaded petrol.

Research into ecological effects of road traffic has greatly increased. The impact of traffic on the surrounding environment is complex, including the disturbance during construction and the pollution from both road material itself and from the traffic once the road is built (Gibson and Farmer, 1986; Harrison et al. 1981; Li et al. 2001; Thornton 1991; $\mathrm{Wu}$ et al. 2006). Motor vehicles introduce a number of pollutants into the environment. In the vicinity of roads, dust and the other traffic-related pollutants such as heavy metals, polycyclic aromatic hydrocarbon particles (PAH) and volatile organic compounds

\footnotetext{
${ }^{1}$ Soil Department, Faculty of Agriculture, Sriwijaya University and Graduate Program, Sriwijaya University, Jl. Padang Selasa No. 524, Bukit Besar, Palembang 30139. Phone: 62-711-354-222, Fax: 711-317-202, e-mail: sabar@mail.pps.unsri.ac.id and sabar63@yahoo.com ${ }^{2}$ Soil Department, Faculty of Agriculture, Sriwijaya University. J Trop Soils, Vol. 15, No. 1, 2010: 25-32 ISSN 0852-257X
} 
(VOCs) exert influence over plant growth and soil. A variety of heavy metals derived from gasoline additives settle into the roadside environment (Gibson and Farmer 1986; Harrison et al. 1981; Li et al. 2001; Sujetovienè and Griauslytė 2008; Thornton 1991; Wu et al. 2006).

Roadside soils and plants may be the most important sink of metals and other pollutants. A variety of heavy metals derived from petrol additives settle into the roadside soils and plants. Hence both roadside soils and plants may contain elevated concentrations of metals which may have detrimental and toxicological effects on both environmental quality and human health (Sinha et al. 1997). The most widely documented metal is lead, but the others are aluminum, iron, cadmium, copper, manganese, titanium, nickel, zinc and boron (Spencer and Port 1988; Sujetovienë and Griauslytë 2008).

More recently Nabuloa et al. (2006) and Viard et al. (2004) reported that the deposition of metals in surface soils decreased with increasing distances from the highway. Although the concentrations of metals in the roadside soil were influenced by meteorological conditions (Othman et al. 1997; Sezgin et al. 2003), traffic density (Garcia and Millán 1994; Nabuloa et al. 2006) and the kind of vehicle in traffic (Nabuloa et al. 2006; Sezgin et al. 2003), and soil parameters (Viard et al. 2004). However, this elevated level of heavy metals is frequently found $200 \mathrm{~m}$ or more from the road (Nurjaya and Saeni 2006).

Heavy metal mobility and solubility in soils are closely related to metal solubility, which is further regulated by adsorption, precipitation and ion exchange reactions in soils. Since $\mathrm{Pb}$ in soils is elemental, it is not subject to chemical degradation. Formation of insoluble heavy metal compounds immobilizes the metal and reduces their bioavailability (Cotter-Howells and Caporn 1996). Chemical conditions in soil are important determinants of heavy metal transport and fate. The importance of interactions between metals and solid phases of soils, soil water, and air within and above soil depends on a variety of chemical factors. Absorption of metals from soil water to soil particles is the most important chemical determinant that limits mobility in soils (Alloway 1995). One of chemical determinants is soil organic matter (SOM). SOM (e.g., humus) adsorbs metals by forming chelate complexes, with carboxyl groups playing a predominant role and has the greatest capacity and strength of bonding with most metals of any soil component. This is illustrated by the commonly observed positive association between solubility of metals (for example $\mathrm{Cu}$ and $\mathrm{Cd}$ ) and SOM content as well as the greater concentration of trace metals in organic rich soils compared with organic-poor soils.

In a study by McGrath et al. (1988) the effect of SOM was determined on concentrations of metals in solution and their extractability from the soil. They found that increased concentrations of SOM depressed the concentration of cupric ions in soil solution as well as the extractability into acetic acid and $\mathrm{CaCl}_{2}$ of both native and added $\mathrm{Cu}$; effects on the extractability of $\mathrm{Zn}$ and $\mathrm{Mn}$, in the other hand, were much smaller. $\mathrm{Cu}$ was observed to be more strongly adsorbed into acid-washed peat, peat and solid humic acids compared with clay minerals or iron oxides.

Although there have been a considerable number of studies on the concentrations of heavy metals in roadside soil and plants, the vast majority have been carried out in developed countries (Chirenje et al. 2003; Dolan et al. 2006; Jarup 2003; Li et al. 2001; Ma and Rao 1997; Silva et al. 2005; Sujetovienè and Griauslyte 2008; Wu et al. 2006). Very few studies have been carried out in developing countries such as Indonesia (Nurjaya and Saeni 2006). Therefore, the present research was undertaken to study lead contamination in the roadside soils and plants in relation to their safe limit. In addition, the effect of organic matter on the solubility of lead in the roadside soils was also investigated.

\section{MATERIALS AND METHODS}

\section{Site Description}

One of major roads in Palembang City was chosen for the study site. The roadsides were planted with oil palms (Elaeis guineensis). There were 350 plants on one side and 317 plants on the other side of the road. The fruit bunches of the oil palms are regularly harvested. The surrounding areas on the right and left of the road were rain-fed paddy field. The average traffic load from 07.00 AM to 05.00 PM was 12,000 vehicles per day. The soil belongs to Ultisols (Soil Survey Staff 1992) or Acrisols (FAO/ UNESCO 1974).

\section{Sampling and Analyses}

For sampling purposes, $10 \%$ of the total plants (35 stands and 31 stands on each site) were chosen. The leaves of the oil palms were collected from each 
of the selected plants. Top soils $(0-20 \mathrm{~cm})$ underneath the canopy of each of the selected plants were also sampled. All the roadside soil samples were air dried at room temperature and sieved through a 2-mm nylon sieve to remove coarse debris. All air-dried soil samples were then ground with a pestle and mortar until all particles passed a 100-mesh nylon sieve and characterized. Soil $\mathrm{pH}$ was measured potentiometrically in a soil- to water- ratio of $5 \mathrm{~g}$ to $25 \mathrm{~mL}$ (designated as $\mathrm{pH}-\mathrm{H}_{2} \mathrm{O}$ ). Exchangeable cations $\left(\mathrm{Ca}, \mathrm{Mg}, \mathrm{K}\right.$, and $\mathrm{Na}$ ) were extracted with $1 \mathrm{M} \mathrm{NH}_{4}^{-}$ $\mathrm{OAc}(\mathrm{pH}$ 7.0) with titration method. Then, the filtrate was washed with deionized water once and twice with 99\% EtOH to remove the salt excess. The ammonium was extracted with $10 \%-\mathrm{NaCl}$ solution twice, followed by reciprocal shaking for $1 \mathrm{~h}$ and centrifugation for $10 \mathrm{~min}$ at $1,000 \mathrm{rpm}$. The ammonium ion content was determined as cation exchange capacity (CEC) by Kjedahl distillation and titration method. Organic Carbon was measured by the Walkley-Black titration method (Walkley and Black 1934), and plant available $\mathrm{Pb}$ was extracted according to EDTA method by Miller et al. (1975) and measured using atomic absorption spectrophotometry. Particle size distribution was analyzed following the hydrometer method (Bouyoucus 1962).

The soil used in the current experiment was highly acidic $\left(\mathrm{pH}_{-}{ }_{\mathrm{H} 2 \mathrm{O}}=4.12\right)$, with low base content $\left(\mathrm{K}-\mathrm{dd}=0.19 \mathrm{cmol}(+) \mathrm{kg}^{-1}, \mathrm{Na}-\mathrm{dd}=0.05 \mathrm{cmol}(+)\right.$ $\mathrm{kg}^{-1}, \mathrm{Ca}-\mathrm{dd}=0.85 \mathrm{cmol}(+) \mathrm{kg}^{-1}$, and $\mathrm{Mg}$-dd $=0.45$ cmol $\left.(+) \mathrm{kg}^{-1}\right)$, very low Organic C content $(5.70 \mathrm{~g}$ $\left.\mathrm{kg}^{-1}\right)$, low CEC $\left(15.23 \mathrm{cmol}(+) \mathrm{kg}^{-1}\right)$, dominated by sand $(43 \%)$ and clay fraction $(40 \%)$ and had initial content of $\mathrm{Pb}$ of $20.01 \mathrm{mg} \mathrm{kg}^{-1}$.

To evaluate the plant and soil contamination level, current findings were compared to the background levels of $\mathrm{Pb}$ in plant and soil, which were $2.0 \mathrm{mg} \mathrm{kg}^{-1}$ and $12.75 \mathrm{mg} \mathrm{kg}^{-1}$ for plant and soil, consecutively (Balai Penelitian Tanah Indonesia 2002).

\section{Pb Emission Potentials}

$\mathrm{Pb}$ Emission Potentials was calculated using the following formula:

where:

$$
\mathrm{E}_{\mathrm{Pb}}=\mathrm{A} \times \mathrm{B} \times \mathrm{C} \times \mathrm{D}
$$

$\mathrm{E}_{\mathrm{Pb}}: \mathrm{Pb}$ Emission Potentials

A: Proportion of vehicle using premium and solar (\%)

B: Total vehicle passing through the road (unit day ${ }^{-1}$ )
C: Fuel consumption for the $3.5 \mathrm{~km}$ of road (L), assuming $1 \mathrm{~L}$ per $10 \mathrm{~km}$ and per $1 \mathrm{~L}$ per $15 \mathrm{~km}$ for gasoline and diesel, consecutively.

$\mathrm{D}$ : $\mathrm{Pb}$ content in petrol and diesel in Palembang is $0.999 \mathrm{~g} \mathrm{~L}^{-1}$ and $0.149 \mathrm{~g} \mathrm{~L}^{-1}$, consecutively (Suyasning 2008).

\section{Soil Organic Matter Amendment}

As mentioned above that the soils used in current experiment had very low organic $\mathrm{C}$ content $(5.70 \mathrm{~g}$ $\mathrm{kg}^{-1}$ ); whereas SOM plays an important role in determining concentrations of metals in soil solution and their extractability from the soil (McGrath et al. 1988). To investigate effects of SOM on the solubility of $\mathrm{Pb}$, the contaminated soils were amended with 30 , 60 and $90 \mathrm{Mg} \mathrm{ha}^{-1}$ of compost to attain organic $\mathrm{C}$ of $10.00,20.10$ and $30.10 \mathrm{~g} \mathrm{~kg}^{-1}$, equivalent to low, moderate and high content of organic $\mathrm{C}$, respectively. Untreated soil $\left(0.00 \mathrm{Mg} \mathrm{ha}^{-1}\right.$ of compost) with inherent level of $\mathrm{Pb}\left(5.70 \mathrm{~g} \mathrm{~kg}^{-1}\right)$ was used as a control. The compost contained 20 to $25 \mathrm{mg} \mathrm{kg}^{-1}$ of total $\mathrm{N}, 5$ to 7 mg kg-1 of available $\mathrm{P}, 30$ to $50 \mathrm{mg} \mathrm{kg}^{-1}$ of $\mathrm{K}_{2} \mathrm{O}$, and had $\mathrm{C} / \mathrm{N}$ ratio of 15 . More importantly that the inherent $\mathrm{Pb}$ content of the compost $\left(3.86 \mathrm{mg} \mathrm{kg}^{-1}\right)$ is much below standard according to SNI 19-7030-2004 $\left(<150 \mathrm{mg} \mathrm{kg}^{-1}\right)$. The compost was added to $1 \mathrm{~kg}$ of soil, thoroughly mixed, potted, then the mixture incubated in room temperature for 30 days. Water level was maintained at field capacity during incubation.

\section{Data Analysis}

Data on $\mathrm{Pb}$ content of incubated soils were expressed as an average of six replicates and treatment effects were determined by analysis of variance. Differences among treatment means were compared by least significant difference (LSD) at $P<0.05$.

\section{RESULTS AND DISCUSION}

\section{Pb Accumulation in Soil}

Current study revealed that $\mathrm{Pb}$ content in roadside soils at the study site was $20.01 \mathrm{mg} \mathrm{kg}^{-1}$. This level was 1.5 times higher than the safe level of $\mathrm{Pb}$ in soil $\left(12.75 \mathrm{mg} \mathrm{kg}^{-1}\right)$ as regulated by Balai Penelitian Tanah Indonesia (2002) and it reveals that the roadside soils at the study site are polluted by $\mathrm{Pb}$. The solubility of metals in soil is predominantly controlled by pH (Henry 2000), cation exchange capacity (Martinez and Motto 2000), organic carbon 
content (Elliot et al. 1986), the oxidation state of the mineral components, and the redox potential of the system (Connell and Miller 1984). The first three factors appear to be predominant contributing factors to the excessive level of $\mathrm{Pb}$ content in the soils of current study.

Soil $\mathrm{pH}$ and CEC levels had a very high significant effect on the amount of $\mathrm{Pb}$ content in the soil samples (Shaikh et al. 2006). In general, soil $\mathrm{pH}$ seems to have the greatest effect of any single factor on the solubility or retention of metals in soils, with a greater retention and lower solubility of metal cations occurring at high soil $\mathrm{pH}$ (Basta et al. 1993). Similar studies elsewhere (Adriano 2001; McLaughlin and Singh 1999) showed that high levels of $\mathrm{pH}$ and CEC tended to be negatively associated with concentrations of heavy metals in soil. However, the soil at the study site was highly acidic ( $\mathrm{pH}$ of 4.12), low CEC (15.23 $\left.\mathrm{cmol}(+) \mathrm{kg}^{-1}\right)$ and very low organic $\mathrm{C}$ content $(5.70 \mathrm{~g}$ $\left.\mathrm{kg}^{-1}\right)$.

In addition to the above factors, the content of heavy metals in roadside soils is also predetermined by traffic intensity on the road (number of vehicles per day), predominant wind direction, soil characteristics and vegetation (Zinkutë et al. 2007). In relation to the current study, number of vehicles, soil characteristics and vegetation seem to be important causes of significantly elevating $\mathrm{Pb}$ content in soil because total vehicles passing through the road were 12,000 vehicles per day (from 07.00 am to $05.00 \mathrm{pm}$ ).

Assuming that $75 \%$ of total vehicles $(12,000$ units per day) passing through the study site was gasolinebased vehicles and the rest (25\%) was diesel-based vehicles, daily emission of $\mathrm{Pb}$ was $731.14 \mathrm{~g} \mathrm{~d}^{-1}$ (626.85 $\mathrm{g} \mathrm{d}^{-1}$ from gasoline-based vehicles and $104.29 \mathrm{~g} \mathrm{~d}^{-1}$ from diesel-based vehicles, respectively) (Tabel 1).

Heavy metal concentrations in roadside soils could also be impacted by longer transportation period (e.g. 20 years), since soil tended to accumulate and persist metals on a relatively long-term period (Garcia and Millán 1994; Kelly et al. 1996). The road in the study site has been operated for almost 20 years.
Therefore, combination of long-term period and heavy traffic density are important contributing factors to the accumulation of $\mathrm{Pb}$ in the soil of the study site. More importantly that the results of the current study confirm that there is a gradual build up of $\mathrm{Pb}$ and probably the other heavy metals in the soil at the study site. Therefore, a constant monitoring of the levels of these metals is required to safeguard farmlands, fish pound and water bodies around this area.

\section{Pb Accumulation in Oil Palm Leaves}

Bioavailability of $\mathrm{Pb}$ at the study site was investigated by measuring $\mathrm{Pb}$ content in leaves of oil palm as a test plant. Similar to $\mathrm{Pb}$ content in the soil at the study site, $\mathrm{Pb}$ content in leaves of oil palm planted along the roadside site was $11.05 \mathrm{mg} \mathrm{kg}^{-1}$. This level was 5.5 times higher than the safe level of $\mathrm{Pb}$ in plant $\left(2.00 \mathrm{mg} \mathrm{kg}^{-1}\right)$ as regulated by Balai Penelitian Tanah Indonesia (2002). Although current data was too small to perform statistical calculations on the dependencies of the two parameters, current result confirms that the high level of $\mathrm{Pb}$ in test plant is proportional to the content of $\mathrm{Pb}$ in soil.

The transfer of $\mathrm{Pb}$ from soils to plants is dependent on three factors; total amount of potentially available $\mathrm{Pb}$ (quantity factor), the activity as well as the ionic ratios of $\mathrm{Pb}$ in the soil solution (intensity factor), and the rate of element transfer from solid to liquid phases and to plant roots (Brummer et al. 1986). These three factors were applicable to the condition of soils at the study site. As explained above that the content of $\mathrm{Pb}$ in soils at the study site was 1.5 time higher than the safe level. Much higher level of $\mathrm{Pb}$ in the leaves of the palm oil was due to the fact that the absorption of $\mathrm{Pb}$ by the test plant occurred not only by roots but also by stomata because diameter of elemental $\mathrm{Pb}(<4 \mu \mathrm{m})$ is smaller than the size of the stomata (length $2 \mu \mathrm{m}$ and width $7 \mu \mathrm{m}$ ). More importantly that there is a possibility that high level of $\mathrm{Pb}$ both in soils and leaves of oil palm at the study site can also be detected in oil palm fruits. However, this hypothesis still requires further investigation.

Table 1. Daily number of vehicles and estimated $\mathrm{Pb}$ emmision.

\begin{tabular}{|c|c|c|c|}
\hline & Gasoline-based * & Diesel-based $* *$ & Total \\
\hline Number of vehicles $\quad\left(\right.$ unit day ${ }^{-1}$ ) & 9,000 & 3,000 & 12,000 \\
\hline Estimated $\mathrm{Pb}$ emmsion $\left(\mathrm{g} \mathrm{day}^{-1}\right)$ & 626.85 & 104.29 & 731.14 \\
\hline
\end{tabular}

Note: *Assumed to be $75 \%$ of the total number of vehicles, ** Assumed to be $25 \%$ of the total number of vehicles. 
Table 2. Effect of $\mathrm{SOM}$ amendment on soluble $\mathrm{Pb}$ in soils.

\begin{tabular}{|c|c|c|c|c|}
\hline \multirow{2}{*}{$\begin{array}{c}\mathrm{SOM} \\
\left(\mathrm{Mg} \mathrm{ha}^{-1}\right)\end{array}$} & \multicolumn{4}{|c|}{ Soluble $\mathrm{Pb}$ at } \\
\hline & $2 \mathrm{WAI} *$ & $\begin{array}{l}\text { Percentage of } \\
\text { Reduction }\end{array}$ & $4 \mathrm{WAI}$ & Percentage of Reduction \\
\hline & ---- $\mathrm{mg} \mathrm{kg}^{-1}----$ & ---- \% ---- & ---- $\mathrm{mg} \mathrm{kg}^{-1}$---- & - $\%$ \% - \\
\hline Control & $11.15 \pm 2.31 \mathrm{~b}$ & $-44.28 * *$ & $7.43 \pm 1.26 \mathrm{~b}$ & $-62.87 * * \quad(-33.36 * * * *)$ \\
\hline 30 & $6.82 \pm 1.89 \mathrm{a}$ & $-38.83 * * *$ & $3.77 \pm 0.74 \mathrm{a}$ & $-49.26 * * *(-44.72 * * * *)$ \\
\hline 60 & $7.19 \pm 2.67 \mathrm{a}$ & $-35.52 * * *$ & $5.34 \pm 2.46 \mathrm{ab}$ & $-28.13 * * *(-25.73 * * * *)$ \\
\hline 90 & $10.19 \pm 2.54 b$ & $-8.61 * * *$ & $6.79 \pm 0.35 \mathrm{~b}$ & $-8.61 * *(-33.36 * * * *)$ \\
\hline
\end{tabular}

\begin{tabular}{l}
\hline $\mathrm{LSD}_{0.05} 1.67$ \\
\hline Note: $*$ WAI = week after incubation, ** as compared with inherent content of $\mathrm{Pb}\left(20.01 \mathrm{mg} \mathrm{kg}^{-1}\right), * * *$ as compared \\
with control, $* * * *$ as compared with $2 \mathrm{WAI}$, values are presented as mean \pm standard deviation $(\mathrm{n}=6)$, values \\
with different letters along a vertical column are statistically different.
\end{tabular}

\section{Organic Matter to Reduce Pb Bioavailability}

Much higher level of $\mathrm{Pb}$ in the soils and the leaves of the palm oil at the study site indicate high bioavailability of $\mathrm{Pb}$ in the soil. Hence, it is necessary to reduce plant-available $\mathrm{Pb}$ concentration in the soils, one of which is through site stabilization. The aim of site stabilization is to rapidly reduce $\mathrm{Pb}$ availability to plants. This can be achieved by adding various agents to the soil, one of which is OM. Changes in $\mathrm{Pb}$ content with $\mathrm{SOM}$ amendment and changes in $\mathrm{Pb}$ with incubation are described in this section.

SOM amendment through the addition of compost significantly $(\mathrm{P}<0.01)$ affected soluble $\mathrm{Pb}$ content in the soils of current study. Although the effects of the addition of OM to heavy metals are frequently varied (Gorlach and Gambus 1992; Narwal and Singh 1998; Schmidt 2003), the addition of organic matter at 30, 60 and $90 \mathrm{Mg} \mathrm{ha}^{-1}$ significantly reduced soluble $\mathrm{Pb}$ in soils as compared with the control in the current study (Table 2). The disagreed findings between the current study and the previous studies are reasonable because $\mathrm{OM}$ is a quite heterogeneous material that can concurrently exert mobilizing and stabilizing effects. Small structural and chemical differences can favor one or the other effect. On the one hand, organic acids released through the decomposition of both the natural SOM and the added OM reduce soil $\mathrm{pH}$, which then increases the concentration of soluble heavy metals in soils. On the other hand, it increases the CEC of soil, providing sorption sites and reducing heavy metals mobility.

In relation to the results obtained in the current study, both argument described above are applicable.
The fact that the addition of OM significantly reduced the soluble $\mathrm{Pb}$ in the soils of the current study (Table 2) implies that the addition of OM provides sorption sites and reduces $\mathrm{Pb}$ mobility. The addition of $\mathrm{OM}$ at $30 \mathrm{Mg} \mathrm{ha}^{-1}$ to correct the level of SOC from very low to low was sufficient to significantly reduce $\mathrm{Pb}$ solubility in the soils of current study. It resulted in a decrease of soluble $\mathrm{Pb}$ with a magnitude of $39 \%$ at 2 weeks after planting (WAI) and $49 \%$ at 4 weeks after planting (WAI) as compared with the control soils (Table 2).

Sorption reactions involving SOM are particularly important with respect to ameliorating the effect of metal contaminants. As widely known that metals including $\mathrm{Pb}$ have a high affinity for humic acids, organo clays, and oxides coated with organic matter (Berti et al. 1996; Elliot et al. 1986). The most common form of interaction between SOM and positively charged ions is via cation exchange reactions (e.g. between negatively charged carboxyl groups and positively charged cations) and is associated with proton replacement from acid functional groups (ligands).

However, further increases in $\mathrm{OM}$ rate to 60 and $90 \mathrm{Mg} \mathrm{ha}^{-1}$ were followed by increases in $\mathrm{Pb}$ level in the soils (Table 2). An increase in OM application to $60 \mathrm{Mg} \mathrm{ha}^{-1}$ triggered a small but not significant increase in soluble $\mathrm{Pb}$ as compared with soluble $\mathrm{Pb}$ in soils receiving $30 \mathrm{Mg} \mathrm{ha}^{-1}$ of $\mathrm{OM}$. Nevertheless, the application of OM up to $90 \mathrm{Mg} \mathrm{ha}^{-1}$ significantly increased the soluble $\mathrm{Pb}$ as compared with those in the soil receiving $30 \mathrm{Mg} \mathrm{ha}^{-1}$ of $\mathrm{OM}$ (Table 2). It indicates that the effort to increase SOC of the soils 
Based on the results obtained it can be concluded

from very low to moderate and high in the current study triggered the increases in the soluble $\mathrm{Pb}$ in the soils through mechanisms described before. Organic acids released through the decomposition of SOM increased soil acidity or at least maintained soil acidity of the current study at $\mathrm{pH}$ of around 4.00 during the incubation, increasing the concentration of soluble $\mathrm{Pb}$ in soils. As explained by Andriano et al. (2002) that the effect of $\mathrm{pH}$ value $<6$ in increasing metal ion activities in soil can be attributed to the decrease in $\mathrm{pH}$-dependent surface charge and chelating by organics of metal hydroxide. Besides continuous loading of $\mathrm{Pb}$ from vehicle emission, the increases in solubility of $\mathrm{Pb}$ as a results of acidification by organic acids possibly facilitates side effects of the higher reported accumulation of $\mathrm{Pb}$ in the leaves of oil palm at the study side. In spite of the increases, the level of soluble $\mathrm{Pb}$ in the soils receiving 60 and $90 \mathrm{Mg}$ ha $^{-1}$ of OM was still much below the safe level of $\mathrm{Pb}$ in soil $\left(12.75 \mathrm{mg} \mathrm{kg}^{-1}\right)$ as regulated by Balai Penelitian Tanah Indonesia (2002).

Although Ma and Dong (2004) described that reported data on the solubility of trace metals in relation to incubation time were often contradictory, current study showed that soluble $\mathrm{Pb}$ in soils decreased with incubation time (Table 2). The levels of soluble $\mathrm{Pb}$ at $4 \mathrm{WAI}$ at all $\mathrm{OM}$ levels decreased with magnitude of ranging from $26 \%$ to $33 \%$ as compared with those at 2 WAI (Table 2). Such reduction occurred not only due to the discontinuation of $\mathrm{Pb}$ loading because the soils were incubated in the laboratory but more importantly also due to the formation of organic acids- $\mathrm{Pb}$ complexes as a result of the decomposition of soil SOM.

Significance of SOM in reducing the soluble $\mathrm{Pb}$ is also evident in control soil. Although the initial content of SOC of the soils used in the current study was very low $\left(5.70 \mathrm{~g} \mathrm{~kg}^{-1}\right)$, incubation under control environment had created a favorable condition for SOM decomposition. The decreases in the soluble $\mathrm{Pb}$ in the control soil from $20.01 \mathrm{mg} \mathrm{kg}^{-1}$ at preincubation time to $11.15 \mathrm{mg} \mathrm{kg}^{-1}$ at $2 \mathrm{WAI}$ and 7.43 mg kg-1 at 4 WAI reflected inherent self-remediation capability of the soils. In spite of the increases, the level of soluble $\mathrm{Pb}$ in the soils receiving 60 and 90 $\mathrm{Mg} \mathrm{ha}^{-1}$ of $\mathrm{OM}$ was still much below the safe level of $\mathrm{Pb}$ in soil. that both roadside soil and oil palm at the study were contaminated by $\mathrm{Pb}$. Adding $\mathrm{OM}$ significantly $(\mathrm{P}<0.01)$ reduced soluble $\mathrm{Pb}$ in the soils. The addition of OM at $30 \mathrm{Mg} \mathrm{ha}^{-1}$ to correct the level of SOC from very low to low was sufficient to significantly reduce the soluble $\mathrm{Pb}$ in the soils of current study. However, the application of $60 \mathrm{Mg} \mathrm{ha}^{-1}$ of $\mathrm{OM}$ triggered the increases in $\mathrm{Pb}$ solubility in the soils and further increases in $\mathrm{OM}$ application to $60 \mathrm{Mg} \mathrm{ha}^{-1}$ resulted in significant increases in soluble $\mathrm{Pb}$ as compared with that in the soil receiving $30 \mathrm{Mg}$ of $\mathrm{OM} \mathrm{ha}^{-1}$.

\section{REFERENCES}

Adriano DC, NS Bolan, BJ Koon, R Naidu, D Lelie, J Vangronsveld and WW Wenzel. 2002. Natural remediation processes bioavailability interactions in contaminated soils 17th. WCSS Symposium 14-21 August 2002, Thailand, 42, p. 501.

Adriano DC. 2001. Trace Elements in Terrestrial Environments: Biogeochemistry, Bioavailability, and Risk of metals. Springer Verlag, NY.

Alloway BJ 1995. Soil processes and the behavior of heavy metals. In: BJ Alloway (ed). Heavy Metals in Soils. $2^{\text {nd }}$ Ed., Blackie, New York, pp. 11-37.

Balai Penelitian Tanah Indonesia. 2002. Penelitian inventarisasi dan pengendalian dampak lingkungan. Laporan akhir. Bagian proyek penelitian dan pengembangan kesuburan tanah dan iklim. (In Indonesian).

Basta NT, DJ Pantone and MA Tabatabai. 1993. Path analysis of heavy metal adsorption by soil. Agron J 85: 1054-1057.

Berti WR and LW Jacobs. 1996. Chemistry and Phytotoxicity of Soil Trace Elements from Repeated Sewage Sludge Applications. J Environ Qual 25: 1025-1032.

Bouyoucus G.J. 1962. Hydrometer method improved for making particle size analysis of soils. Agron J 54: 461-465.

Brümmer G, J Gerth and U Herms. 1986. Heavy metal species, mobility and availability in soils. $Z$ Pflanzenernaehr Bodenkd 149: 382-398.

Chirenje T, LQ Ma, C Clark and M Reeves. 2003. Cu, Cr and As distribution in soils adjacent to pressuretreated decks, fences and poles. Environ Pollut 124: 407-417.

Connell DW and GJ Miller. 1984. Chemistry and Ecotoxicology of Pollution. John Wiley \& Sons, NY, pp. 444.

Cotter-Howells J and S Caporn. 1996. Remediation of contaminated land by formation of heavy metal phosphates. Appl Geochem 11: 335-342.

Dolan MJ, H Van Bohemen, P Whelan, KF Akbar, V O'Malley, G O'Leary and PJ Keizer. 2006. Towards 
the sustainable development of modern road ecosystem. In: J Davenport and JL Davenport (eds). The Ecology of Transportation: Managing Mobility for the Environment. Springer Netherlands, pp. 275331.

Elliot HA, MR Liberali and CP Huang. 1986. Competitive adsorption of heavy metals by soils. J Environ Qual 15: 214-219.

FAO/UNESCO. 1974. Soil map of the world. Vol 1. Unesco, Paris, 59 pp.

Garcia R and E Millán. 1994. Heavy metal contents from road soil in Guipuzcoa (Spain). The science of the Total Environ 14: 157-161.

Gibson MG and JG Farmer. 1986. Multi-step chemical extraction of heavy metals from urban soils. Environ Pollut Bull 11: 117-135.

Gorlach E and F Gambus. 1992. A study of the effect of sorption and desorption of selected heavy metals in soils on their uptake by plants. Zesz Probl Postepow Nauk Roln 398:25-32.

Harrison RM, DPH Laxen and SJ Wilson. 1981. Chemical association of lead, cadmium, copper, and zinc in street dust and roadside soil. Environ Sci Technol 15: $1378-138$.

Henry JR. 2000. An Overview of Phytoremediation of Lead and Mercury. NNEMS Report. Washington, D.C, pp. 3-9.

Jarup L. 2003. Hazards of heavy metal contamination. Brazilian Med Bull 68: 425-462.

Kelly J, I Thornton and PR Simpson. 1996. Urban Geochemistry: a study of influence of anthropogenic activity on heavy metal content of soils in traditionally industrial and non-industrial areas of Britain. Appl Geochem 11: 363-370.

Li X, CS Poon and PS Liu. 2001. Heavy metal contamination of urban soils and street dusts in Hong Kong. Appl Geochem 16: 1361-1368.

Ma LQ and GN Rao. 1997. Chemical Fractionation of Cadmium, Copper, Nickel, and Zinc in Contaminated Soils. J Environ Qual 26: 259-264.

Ma LQ and Y Dong. 2004. Effects of incubation on solubility and mobility of trace metals in two contaminated soils. Environ Pollut 130: 301-307.

Martinez CE and HL Motto. 2000. Solubility of lead, zinc, and copper added to mineral soils. Environ Pollut 107: 153-158.

McGrath SP, JR Sanders and MH Shalaby. 1988. The effects of soil organic matter levels on soil solution concentrations and extractibilities of manganese, zinc and copper. Geoderma 42: 177-188.

McLaughlin MJ and BR Singh. 1999. Cadmium in soils and plants. Kluwer Academic Publishers, Netherlands.

Miller JE, JJ Hasset and DE Koeppe. 1975. The effect of soil properties and extractable lead levels on lead uptake by soybeans. Commun Soil Sci Plant Anal 6:339-347.

Nabuloa G, H Oryem-Origa and M Diamond. 2006. Assessment of lead, cadmium, and zinc contamination of roadside soils, surface films, and vegetables in Kampala City, Uganda. Environ Res 101: 42-52.

Narwal RP and BR Singh. 1998. Effect of organic materials on partitioning, extractability and plant uptake of metals in an alum shale soil. Water Soil Pollut 103: 405-421.

Nurjaya EZ and SM Saeni. 2006. Pengaruh ameliorant terhadap kadar $\mathrm{Pb}$ tanah, serapannya serta hasil tanaman bawang merah pada inceptisol. J I Pert Indon 8 (2): 110-119.

Othman I, M Al Oudat and MS Al Masri. 1997. Lead levels in roadside soils and vegetation of Damascus city. Sci Total Environ 207: 43-48.

Schmidt U. 2003. Enhancing Phytoextraction: The Effect of Chemical Soil Manipulation on Mobility, Plant Accumulation, and Leaching of Heavy Metals. J Environ Qual 32: 1939-1954.

Sezgin N, HK Ozcan, G Demir, S Nemlioglu and C Bayat. 2003. Determination of heavy metal concentrations in street dusts in Istanbul E-5 highway. Environ Int 29: 979-985.

Shaikh M, N Moleele, GE Ekosse, O Totolo and J Atlhopheng. 2006. Soil Heavy Metal Concentration Patterns at Two Speed Zones along the GaboroneTlokweng Border Post Highway, Southeast Botswana. J Appl Sci Environ Manag 10 (2): 135-143.

Silva ALO, PRG Barrocas, SC Jacob and JC Moreira. 2005. Dietary intake and health effects of selected toxic elements. Brazilian J Plant Physiol 17:79-93.

Sinha S, M Gupta and P Chandra. 1997. Oxidative stress induced by iron in Hydrilla verticillata (1.f.) Royle: response of antioxidants. Ecotoxicol Environ Safety 38: 286-291.

Soil Survey Staff. 1992. Keys to soil taxonomy. $5^{\text {th }}$ Ed. Soil Management Support Services Technical Monograph No. 19, Blackburg, Virginia, 556 p.

Spencer HJ and GR Port. 1988. Effects of roadside conditions on plants and insects. II. Soil conditions. J Appl Ecol 25: 709-715.

Sujetovienë G and L Griauslytë. 2008. Toxicity Assessment of Roadside Soil Using Wild Oat (Avena sativa L.) and Cress (Lepidium sativum L.) Morphometric and Biochemical Parameters. Environ Res Eng Manag 4 (46): 29-35.

Suyasning. 2008. Temukan kadar Kualitas Premium di Indonesia. Available online at http://www.kompas. com/kompos-cetak/0107/08/iptek/timb22.htm, January 16, 2009.

Thornton I. 1991. Metal contarnination of soils in urban areas. In: P Bullock and PJ Gregory (Eds). Soils in the Urban Environment. Blackwell, pp. 47-75. 
Viard B, F Pihan, S Promeyrat and J Pihan. 2004. Integrated assessment of heavy metal $(\mathrm{Pb}, \mathrm{Zn}, \mathrm{Cd})$ highway pollution: Bioaccumulation in soil, Graminaceae and landsnails. Chemosphere 55 (10): 1349-1359.

Walkley A and IA Black. 1934. An examination of the Degtjareff method for determining soil organic matter, and proposed modification of the chromic acid titration method. Soil Sci 37: 29-38.
Wu SC, YM Luo, KC Cheung and MH Wong. 2006. Influence of bacteria on $\mathrm{Pb}$ and $\mathrm{Zn}$ speciation, mobility and bioavailability in soil: a laboratory study. Environ Pollut 144: 765-773.

Zinkute R, E Brannvall and R Taraškevičius. 2007. Variation of trace element accumulation in topsoil near the Vilnius-Kaunas highway. Geologija 58: 1-9. 